\title{
ANALISIS BREAK EVEN POINT (BEP) USAHA TERNAK SAPI PERAH “TAREKAT MSC" DI KELURAHAN PINARAS KOTA TOMOHON
}

\author{
Priska. K. Londa ${ }^{*)}$, P. O.V Waleleng**), R. A. J. Legrans-A ${ }^{* *)}$, \\ dan Femi H. Elly ${ }^{* * *}$ \\ Fakultas Peternakan Universitas Sam Ratulangi Manado, 95115. \\ email: priskalonda@yahoo.com
}

\begin{abstract}
ABSTRAK
Usaha ternak sapi perah "Tarekat MSC" di Kelurahan Pinaras Kota Tomohon merupakan salah satu usaha ternak sapi perah di Sulawesi Utara. Permasalahannya, tingkat produktivitas dari ternak sapi perah yang dikelola adalah rendah. Pengelola/peternak dituntut harus berpikir bagaimana mengalokasikan sarana produksi (input produksi) yang ada seefisien mungkin. Hal ini harus dilakukan untuk meningkatkan produksi, mencapai Break Even Point (BEP) dan keuntungan yang maksimal. Tujuan penelitian untuk mengetahui Break Even Point (BEP) usaha ternak sapi perah "Tarekat MSC" di Kelurahan Pinaras Kota Tomohon. Metode penelitian yang digunakan adalah metode studi kasus . Analisis yang digunakan adalah analisis Break Even Point (Rp) dan Break Even Point (unit). Hasil penelitian menunjukkan bahwa produksi susu yang dihasilkan sebesar 5,8 liter/ekor/hari dengan pemeliharaan 27 ekor, sementara yang produksi hanya 6 ekor. Biaya produksi yang dikeluarkan terdiri dari biaya tetap sebesar Rp. 7.291.750 dan biaya variabel sebesar $\mathrm{Rp}$. 19.221.000. Penerimaan yang diperoleh sebesar Rp. 15.900.000 dari hasil penjualan susu sebanyak 1060 liter dengan harga Rp. 15.000 per liter. Analisis Break Even Point (BEP) diperoleh penerimaan (Rp) adalah $\mathrm{Rp}$. 26.512.750 dan Break Even Point (BEP) unit adalah 1767,52. Break Even Point
\end{abstract}

\footnotetext{
* Alumni Fakultas Peternakan

** Jurusan Sosial Ekonomi Peternakan
}

(BEP) usaha ternak sapi perah "Tarekat MSC" dapat dicapai pada penerimaan penjualan susu sebesar Rp. 26.512.750 dengan volume produksi susu sebanyak $1.767,52$ liter atau pada saat jumlah sapi laktasi sebanyak 10,16 ekor.

Kata Kunci: Sapi perah, Break Even Point (BEP).

ABSTRACT
ANALYSIS BREAK EVEN POINT
(BEP) DAIRY CATTLE BUSINESS
"TAREKAT MSC" IN THE VILLAGE
PINARAS TOMOHON. Dairy cattle
business "Tarekat MSC" in the Village
Pinaras, Tomohon is one of the dairy
cattle business in North Sulawesi. The
problem is, the level of productivity of
dairy cattles are managed is low. Business
/ farmer sued to think how to allocate the
means of production (inputs) that is as
efficient. This must be done to increase
production, reaching Break Even Point
(BEP) and the maximum profit. The
purpose of research to find out the Break
Even Point (BEP) dairy cattle business
"Tarekat MSC" in the Village Pinaras,
Tomohon. The research method used was
the case study method. The analysis used
is the analysis of the Break Even Point
(Rp) and Break Even Point (unit). The
results showed that milk production by
5.8 liters / head / day with maintenance of
27 tails, while the production is only 6
tails. Production costs incurred consist of
fixed costs Rp. $7,291,750$ and variable
costs Rp. 19,221,000. Revenue earned Rp.
15.9 million from the sale of as much as
1060 liters of milk at a price of Rp.
15,000 per liter. Analysis Break Even
Point (BEP) obtained admission (Rp) was


Rp. 26,512,750 and Break Even Point (BEP) unit is 1767.52. Break Even Point (BEP) dairy cattle business "Tarekat MSC" can be achieved in milk sales revenue of Rp. 26,512,750 with milk production volume 1767.52 liters or when the number of lactating cows as much as 10.16 tails.

\section{Keywords: Dairy cattle, Break Even Point (BEP)}

\section{PENDAHULUAN}

Pembangunan pertanian, pada dasarnya bertujuan untuk meningkatkan produksi menuju swasembada, memperluas kesempatan kerja dan meningkatkan taraf hidup rakyat. Untuk mencapai tujuan tersebut, sub sektor peternakan meletakkan salah satu prioritas utamanya pada pengembangan usaha ternak sapi perah (Putranto, 2006).

Sapi perah merupakan salah satu ternak yang produksi utamanya adalah susu. Usaha sapi perah untuk menghasilkan susu segar sangat prospektif karena masih terdapat kesenjangan yang cukup besar antara ketersediaan dan permintaan susu. Kebutuhan protein hewani yang berasal dari susu di Indonesia sebesar $5 \mathrm{~kg} / \mathrm{kapita} / \mathrm{tahun}$, tetapi hanya sekitar $32 \%$ dipenuhi dari produksi dalam negeri dan sisanya sekitar $68 \%$ harus diimpor. Perkembangan usaha peternakan sapi perah di Indonesia terus meningkat dari tahun ke tahun, salah satunya akibat peningkatan permintaan susu dan daging. Peningkatan permintaan sejalan dengan meningkatnya jumlah penduduk dan kesadaran masyarakat terhadap gizi seimbang akan sumber protein hewani.

$\begin{array}{rrrr}\text { Di } & \begin{array}{r}\text { Sulawesi } \\ \text { wilara }\end{array} & \text { terdapat } \\ \text { beberapa } & \text { wilayah } & \text { yang } & \text { sedang }\end{array}$

dikembangkan menjadi kawasan pengembangan peternakan sapi perah salah satunya di Kota Tomohon. Kota Tomohon yang terletak pada ketinggian 700-800 meter dari permukaan laut, ditetapkan sebagai kawasan sentra produksi peternakan. Usaha ternak sapi perah "Tarekat MSC" di Kelurahan Pinaras Kota Tomohon merupakan salah satu peternakan sapi perah yang sedang dikembangkan. Produktivitas ternak sapi yang ada rendah, sehingga perlu dilakukan pengkajian mengenai titik pulang pokok usaha ternak sapi perah "Tarekat MSC" dengan produktivitas dan populasi ternak sapi yang ada.

Ternak sapi perah memiliki potensi untuk dikembangkan di Sulawesi Utara khususnya di Kota Tomohon. Hal ini ditunjang oleh kondisi wilayah Kota Tomohon yang memiliki ketinggian 700-800 meter dari permukaan laut dengan suhu berkisar $23^{0}-24^{0} \mathrm{C}$. Permasalahannya, tingkat produktivitas dari ternak sapi perah yang dikelola "Tarekat MSC" di Kelurahan Pinaras Kota Tomohon rendah. Pengelola/peternak dituntut harus berpikir bagaimana mengalokasikan sarana produksi (input produksi) yang ada seefisien mungkin. Hal ini harus dilakukan untuk meningkatkan produksi, mencapai Break Even Point (BEP) dan keuntungan yang maksimal. Berdasarkan permasalahan tersebut maka dapat dirumuskan masalah : Berapa Break Even Point (BEP) usaha ternak sapi perah "Tarekat MSC" di Kelurahan Pinaras Kota Tomohon. Adapun tujuan penelitian ini adalah untuk mengetahui Break Even Point (BEP) usaha ternak sapi perah 
"Tarekat MSC" di Kelurahan Pinaras Kota Tomohon.

\section{MATERI DAN METODE PENELITIAN}

Penelitian ini dilaksanakan pada usaha peternakan sapi perah yang dikelola oleh Yayasan "Tarekat MSC" di Kelurahan Pinaras dengan menggunakan metode studi kasus. Data yang diperoleh adalah data primer dan sekunder. Data primer diperoleh melalui pengamatan dan wawancara langsung dengan pengelola usaha sapi perah serta berpedoman pada daftar pertanyaan yang telah disediakan. Sedangkan data sekunder diperoleh dari Kantor Dinas Pertanian dan Peternakan Propinsi Sulawesi Utara, Kantor Dinas Pertanian, Peternakan dan Perikanan Kota Tomohon. Jenis data yang digunakan yaitu data time series. Definisi variabel dan pengukurannya adalah (i) Populasi ternak sapi perah adalah diukur jumlah ternak sapi perah yang ada di usaha peternakan "Tarekat MSC" (ekor); (ii) Produksi susu adalah jumlah susu sapi yang dihasilkan setiap hari (liter/hari); (iii) Tenaga kerja adalah jumlah orang yang bekerja dalam usaha peternakan sapi perah (orang/hari); (iv) Jumlah pakan adalah banyaknya pakan baik pakan hijauan, dedak padi dan ampas tahu yang diberikan setiap hari untuk ternak sapi perah (kg/hari); (v) Luas kandang adalah luas kandang yang ditempati sapi perah $\left(\mathrm{m}^{2}\right)$ (vi) Biaya tetap (fixed cost) adalah biaya yang dikeluarkan untuk pembelian bibit sapi perah, pembuatan kandang, gudang susu, mesin/peralatan dan pajak, diukur berdasarkan nilai depresiasi per bulan (Rp/bulan) (vii) Biaya variabel (variable cost) adalah biaya yang dikeluarkan untuk pembelian pakan, upah tenaga kerja, obat-obatan, transportasi, listrik (Rp/bulan); (viii) Harga susu segar adalah harga jual susu (Rp/liter); (ix) Penerimaan adalah jumlah uang yang diterima dari hasil penjualan susu (Rp/bulan); (x) Keuntungan dihitung dari selisih penerimaan penjualan susu dan total biaya (Rp/bulan); (xi) Break Even Point adalah suatu keadaan usaha tidak mengalami keuntungan dan kerugian. BEP dihitung dalam BEP (rupiah) dan BEP (liter). Model analisis yang digunakan dalam penelitian ini adalah analisis Break Even Point (Riyanto 2001).

\section{HASIL DAN PEMBAHASAN}

Usaha peternakan sapi perah "Tarekat MSC" terletak di Kelurahan Pinaras Kecamatan Tomohon Selatan merupakan usaha yang dikelola oleh Yayasan Katolik. Usaha peternakan sapi perah dimulai pada akhir tahun 2009 yang dahulunya merupakan milik dari dr. Hans Wewengkang dan pada tahun 2012 diserahkan kepada Yayasan "Tarekat MSC" untuk dikelola. "Tarekat MSC" ini merupakan gabungan para misionaris hati kudus. Bibit ternak sapi perah didatangkan dari Jawa dan Makassar sebanyak 22 ekor. Jenis sapi perah tersebut adalah ternak sapi perah FH. Populasi ternak sapi perah bervariasi berdasarkan umur dan jenis kelamin. Ternak sapi perah yang berumur 1-6 bulan berjumlah 3 ekor terdiri dari 2 jantan dan 1 betina, sedangkan ternak sapi perah umur 1-3 tahun berjumlah 
24 ekor yang terdiri dari 23 ekor betina dan 1 ekor pejantan.

Jumlah sapi perah laktasi 6 ekor $(22,2 \%)$ dari total jumlah sapi perah yang ada. Persentase tersebut tidak ideal karena menurut Siregar (1995) dalam pemeliharaan sapi perah jumlah induk laktasi harus lebih besar dari $80 \%$ dari jumlah keseluruhan sapi perah di sebuah perusahaan. Data yang ada menunjukkan komposisi sapi laktasi sangat jauh di bawah $80 \%$. Hal ini mengindikasikan keadaan usaha ternak sapi perah "Tarekat MSC" kurang baik dibandingkan dengan penelitian Siregar (1995).

Kandang sapi perah yang baik adalah kandang yang sesuai dan memenuhi persyaratan. Berdasarkan pengamatan yang dilakukan pada usaha ternak sapi perah "Tarekat MSC" menunjukkan lokasi kandang cukup baik. Hal ini ditunjang dari jarak kandang dengan pemukiman penduduk cukup jauh. Konstruksi kandang kuat dan tahan lama sesuai pendapat BP3 (2009). Kandang sapi perah dilengkapi dengan bak pakan dan saluran pembuangan. Tiang kandang terbuat dari kayu dan besi serta beratapkan seng. Lantai semen, tetapi kemiringannya tidak sesuai dengan konstruksi kandang sapi perah. Kapasitas kandang sekitar 30 ekor, tetapi hanya terisi 27 ekor.

Berdasarkan pengamatan yang dilakukan, pemberian pakan dilakukan 2 kali sehari yaitu pagi dan sore hari. Pakan hijauan yang diberikan berupa rumput. Pakan tambahan berupa dedak padi dan ampas tahu. Pakan hijauan rumput yang diberikan rata-rata sekitar 17 kg/ekor/hari. Pemberian dedak padi rata-rata sekitar 5 kg/ekor/hari. Ampas tahu yang diberikan rata-rata 6 kg/ekor/hari. Ampas tahu diberikan apabila ada persediaan.

Pemberian air minum dilakukan secara ad-libitum. Hal ini sesuai pendapat Syarief dan Sumoprastowo (1985) bahwa air minum diberikan secara ad-libitum, karena sapi rata-rata membutuhkan 34 kali dari jumlah susu yang dihasilkan. Pentingnya kebutuhan air juga karena susu yang dihasilkan $87 \%$ berupa air dan sisanya adalah bahan kering (Sudono, dkk. 2003).

Berdasarkan hasil pengamatan yang dilakukan pada usaha sapi perah "Tarekat MSC", pemerahan dilakukan 2 kali sehari yaitu pagi dan sore hari. Hal ini sesuai dengan pendapat Sudono, dkk (2003), umumnya sapi diperah 2 kali sehari, pagi dan sore hari. Pemerahan yang dilakukan lebih dari 2 kali sehari, biasanya dilakukan terhadap sapi-sapi yang berproduksi tinggi. Misalnya sapi yang berproduksi 20 - 25 liter dapat diperah 3-4 kali sehari. Manajemen pemerahan pada usaha ternak sapi perah "Tarekat MSC" sesuai penelitian dibagi atas : (1) Persiapan pemerahan, pembersihan kandang dilakukan sebelum pemerahan, hal ini untuk menjaga supaya susu hasil perahan nantinya tidak tercemar oleh bau dan bakteri. Peralatan yang akan digunakan berupa ember dibersihkan dan daerah lipat paha sapi serta ambing sapi yang akan diperah dicuci karena bagian tersebut cenderung mengotori air susu dengan kotoran yang menempel, (2) Pelaksanaan Pemerahan, teknik pemerahan dilakukan dengan menggunakan tangan. Proses pemerahan menggunakan pelicin, yaitu mentega. Penggunaan pelicin bertujuan untuk memudahkan dalam 
pemerahan dan meminimumkan terjadinya luka bahkan infeksi pada puting. Air susu perahan pertama dibuang. Pemerahan dilakukan selama 5 menit/ekor. Setelah pemerahan selesai, air susu dituangkan ke dalam milkcan dan dibawa ke gudang penyimpanan susu dan siap untuk dikemas tanpa dilakukan pasteurisasi.

Berdasarkan pengamatan, tenaga kerja yang dipekerjakan sebanyak 3 orang dengan jumlah pemeliharaaan sapi perah sebanyak 27 ekor. Upah yang diberikan sebesar Rp. 1.300.000 per orang per bulan.Tenaga kerja yang ada mengerjakan semua pekerjaan mulai dari membersihkan kandang, memandikan sapi, mencari rumput, memberikan makan dan minum, pemerahan susu dan mengawinkan ternak sapi jika ada ternak yang siap untuk dikawinkan serta pengemasan susu.

Total curahan waktu tenaga kerja untuk usaha ternak sapi perah "Tarekat MSC" adalah sebesar 5,5 jam/hari dengan 3 orang pekerja. Ratarata jam kerja/hari/orang sekitar 1,8 jam. Jam kerja per hari per orang ini lebih rendah dibandingkan dengan pemeliharaan ternak sapi perah di Jawa dan Garut rata-rata 8 jam per orang per hari untuk 5 ekor sapi dewasa (Siregar, 1996).

Curahan waktu yang terbanyak adalah untuk memandikan sapi yaitu $27,2 \%$ dari total curah waktu kerja. Hal ini disebabkan karena untuk melakukan pemerahan maka ternak sapi perah dalam keadaan bersih. Sedangkan menurut penelitian Siregar (1993), curahan waktu tenaga kerja yang dibutuhkan dalam pemeliharaan sapi perah sekitar $60 \%$ berada di belakang sapi perah, $15 \%$ berada di bagian depan sapi perah dan $25 \%$ lagi berada di bagian lain termasuk dikamar susu. Artinya, waktu yang paling lama dalam pemeliharaan sapi perah adalah di bagian belakang sapi perah.

Kesehatan ternak merupakan salah satu faktor penting yang mempengaruhi produksi ternak termasuk produksi susu pada sapi perah. Sapi-sapi perah yang dipelihara harus dilakukan vaksinasi dan sanitasi kebersihan kandang untuk produksi susu yang optimal. Berdasarkan hasil penelitian bahwa permasalahan penyakit sapi perah pada peternakan "Tarekat MSC" sampai saat ini belum ada. Pemeliharaan sapi perah tujuan utamanya adalah produksi susu. Produksi susu pada usaha ternak sapi perah "Tarekat MSC" sesuai hasil penelitian rata-rata sekitar 5,8 liter/ekor/hari lebih rendah dibandingkan produksi susu sapi di Jawa Timur menurut Suthoni (2008) sekitar 11,04 liter/ekor/hari. Produksi susu menurut Hertika (2008) sekitar 14,99 liter/ekor/hari dan Putranto (2006) produksi rata-rata sapi perah FH di Indonesia sekitar 10 liter/ekor/hari. Rendahnya produksi susu pada usaha peternakan sapi perah "Tarekat MSC" disebabkan oleh manajemen usaha ternak sapi perah yang kurang baik. Manajemen yang kurang baik dapat dilihat dari pemberian pakan hijauan yang belum sesuai dengan kebutuhan ternak sapi perah. Menurut, Sudono, dkk. (2003), mengatakan bahwa pakan sapi perah menjadi faktor utama yang dapat mempengaruhi produksi dan kualitas susu. Selain itu, pakan dapat mempengaruhi kesehatan sapi, baik kesehatan tubuhnya maupun kesehatan 
reproduksinya. Secara umum, pakan sapi perah terdiri dari $60 \%$ hijauan dan $40 \%$ konsentrat. Pakan berupa rumput bagi sapi dewasa umumnya diberikan sebanyak $10 \%$ dari bobot badan dan pakan tambahan sebanyak $1-2 \%$ dari bobot badan. Sapi yang sedang menyusui (laktasi) memerlukan makanan tambahan sebesar $25 \%$ hijauan dan konsentrat dalam ransumnya. Selain itu, rendahnya produksi susu disebabkan oleh kualitas bibit sapi perah yang tidak sesuai dengan daerah asalnya.

Hasil penelitian menunjukkan bahwa selama ini pemasaran susu sapi hanya di SMU Lokon Tomohon dan di salah satu industri pembuatan roti dan kue di Manado. Kedua konsumen ini merupakan pelanggan tetap setiap minggu. Susu sapi dikemas dengan kemasan bermerk "Tomory". Berdasarkan hasil penelitian, dapat diketahui bahwa saluran pemasaran susu sapi yang ada yaitu peternak mengantar langsung kepada konsumen, akan tetapi konsumen telah lebih dahulu memesan berapa banyak yang dibutuhkan. Sedangkan, menurut penelitian Handayani dan Nurlaila (2011) saluran pemasaran susu segar di Kabupaten Klaten ada 2 saluran yaitu :

Saluran I: peternak $\rightarrow$ TPS $\rightarrow$ KUD $\rightarrow$ IPS, home industry, pedagang pengecer, dan konsumen.

Saluran II : peternak $\rightarrow$ pedagang pengumpul $\rightarrow$ pedagang luar Kecamatan Jatinom.

Menurut Soekardono (2009), biaya produksi secara teori terdiri dari biaya tetap dan biaya variabel. Biaya tetap adalah biaya-biaya dalam keadaan terbatas tidak berubah mengikuti perubahan aktivitas produksinya. Biaya tetap dapat dilihat pada Tabel 1.

Tabel 1. Biaya Tetap Usaha Ternak Sapi Perah “Tarekat MSC" Per Bulan

\begin{tabular}{|c|c|c|c|c|c|c|}
\hline No & Jenis Biaya & $\begin{array}{c}\text { Jumlah } \\
\text { unit }\end{array}$ & Harga (Rp) & $\begin{array}{l}\text { Total } \\
(\mathrm{Rp})\end{array}$ & $\begin{array}{l}\text { Penyusutan } \\
\text { per bulan }\end{array}$ & $\%$ \\
\hline 1. & Kandang & $180 \mathrm{~m}^{2}$ & 45.000 .000 & 45.000 .000 & $166.666,67$ & 2,28 \\
\hline 2. & $\begin{array}{l}\text { Bibit sapi perah } \\
\text { (Jawa) } \\
\text { Bibit sapi perah } \\
\text { (Makassar) }\end{array}$ & $\begin{array}{l}4 \\
18\end{array}$ & $\begin{array}{l}17.000 .000 \\
14.000 .000\end{array}$ & $\begin{array}{r}68.000 .000 \\
252.000 .000\end{array}$ & $\begin{array}{c}850.000,00 \\
3.937 .500,00\end{array}$ & 65,65 \\
\hline 3. & Gudang Susu & 1 & 60.000 .000 & 60.000 .000 & $208.333,33$ & 2,86 \\
\hline 4. & Mesin diesel & 1 & 2.500 .000 & 2.500 .000 & $20.833,33$ & 0,29 \\
\hline 5. & Ember & 5 & 6.000 & 30.000 & 500,00 & 0,01 \\
\hline 6. & Milkcan & 4 & 500.000 & 2.000 .000 & $16.666,67$ & 0,24 \\
\hline 7. & Tong air & 1 & 150.000 & 150.000 & $2.500,00$ & 0,03 \\
\hline 8. & Freezer & 2 & 3.500 .000 & 7.000 .000 & $58.333,33$ & 0,8 \\
\hline 9. & Pajak & & 1.900 .000 & 1.900 .000 & $1.900 .000,00$ & 26,06 \\
\hline 10. & Container IB & 1 & 15.000 .000 & 15.000 .000 & $125.000,00$ & 1,71 \\
\hline 11. & Selang air & $100 \mathrm{~m}$ & 6.500 & 650.000 & $5.416,67$ & 0,07 \\
\hline \multicolumn{3}{|c|}{ Total Biaya Tetap/Bulan } & & & $7.291 .750,00$ & 100 \\
\hline
\end{tabular}


Data pada Tabel 1 menunjukkan biaya tetap yang dikeluarkan usaha ternak sapi perah "Tarekat MSC" adalah sebesar Rp. 7.291.750. Perhitungan biaya tetap dalam penelitian ini dihitung dari biaya penyusutan kandang, bibit ternak, gudang susu, mesin-mesin dan peralatan._Biaya tetap yang terbesar adalah biaya bibit sapi perah yaitu sebesar $65,65 \%$ dari total biaya tetap. Hal ini disebabkan karena biaya bibit sudah termasuk biaya transportasi. Hal ini ditunjang dengan penelitian
Sundari dan Katamso (2010), biaya tetap terbesar yang dikeluarkan adalah biaya bibit sapi perah yaitu sebesar $6,89 \%$ dari total biaya produksi.

Biaya variabel adalah biaya yang jumlahnya berubah kira-kira sebanding dengan besarnya produksi. Biaya variabel usaha ternak sapi perah "Tarekat MSC" berupa biaya pakan hijauan, dedak padi, ampas tahu, semen beku, teanaga kerja, listrik, obat-obatan, plastik susu dan transportasi. Total biaya variabel sebesar Rp. 19.221.000.

Tabel 2. Biaya Variabel Usaha Ternak Sapi Perah “Tarekat MSC" Per Bulan

\begin{tabular}{|c|c|c|c|c|c|}
\hline No. & Jenis Biaya & $\begin{array}{c}\text { Jumlah } \\
\text { unit }\end{array}$ & Harga (Rp) & Total (Rp) & $\begin{array}{c}\text { Persentase } \\
\%\end{array}$ \\
\hline 1. & $\begin{array}{l}\text { Pakan : } \\
\text { - Hijauan }(\mathrm{kg}) \\
\text { - Dedak padi (kg) } \\
\text { - Ampas tahu (krg) } \\
\text { Total }\end{array}$ & $\begin{array}{r}13.722 \\
3.750 \\
91\end{array}$ & $\begin{array}{r}500,00 \\
1200,00 \\
10.000,00\end{array}$ & $\begin{array}{r}6.861 .000,00 \\
4.500 .000,00 \\
910.000,00 \\
12.271 .000,00\end{array}$ & $\begin{array}{r}35,70 \\
23,41 \\
4,73 \\
63,84\end{array}$ \\
\hline 2. & Semen beku & & $50.000,00$ & $50.000,00$ & 0,26 \\
\hline 3. & Tenaga kerja (org) & 3 & $1.300 .000,00$ & $3.900 .000,00$ & 20,29 \\
\hline 4. & Listrik & & $2.000 .000,00$ & $2.000 .000,00$ & 10,40 \\
\hline 5. & Plastik Susu (lbr) & 500 & 1500,00 & $750.000,00$ & 3,91 \\
\hline 6. & Obat-obatan & & $50.000,00$ & $50.000,00$ & 0,26 \\
\hline 7. & Transportasi & & $200.000,00$ & $200.000,00$ & 1,04 \\
\hline \multicolumn{4}{|c|}{ Total Biaya Variabel/Bulan } & 19.221 .000 & 100 \\
\hline
\end{tabular}

Data pada Tabel 2 menunjukkan bahwa biaya pakan adalah biaya yang terbesar $(63,84 \%)$ dari total biaya variabel. Biaya tersebut lebih tinggi dibandingkan biaya pakan yang dikeluarkan usaha pemeliharaan sapi perah di Kabupaten Sleman Yogyakarta. Berdasarkan penelitian Sundari dan Katamso (2010) biaya pakan sebesar $61,28 \%$.

Penerimaan adalah nilai rupiah yang diterima oleh peternak/perusahaan dari hasil penjualan susu (liter). Penerimaan merupakan hasil penjualan susu dikali dengan harga. Sulthoni (2008), mengatakan bahwa sumber penerimaan terbesar dalam usaha sapi perah adalah penjualan susu. Penerimaan yang berasal dari penjualan susu dipengaruhi oleh jumlah ternak yang dimiliki. Semakin banyak ternak yang dimiliki maka produksi susu yang dihasilkan semakin banyak dan berpengaruh terhadap penjualan susu. Penjualan 
susu yang semakin banyak akan berpengaruh terhadap penerimaan. Hasil penelitian menunjukkan, penjualan susu pada usaha ternak sapi perah "Tarekat MSC" sebesar 1.060 liter dengan harga susu per liter Rp.15.000. Penerimaan yang diperoleh sebesar Rp.15.900.000 per bulan. Jumlah sapi perah mempengaruhi penerimaan suatu usaha sapi perah. Tujuan utama dalam pembukaan usaha yang direncanakan adalah keuntungan. Menurut Prawirokusumo (1990), keuntungan adalah jumlah rupiah yang didapat dari pendapatan bersih suatu usaha. Keuntungan merupakan selisih antara penerimaan total dengan biaya (biaya tetap dan biaya tidak tetap).

Keuntungan dari usaha peternakan sapi perah "Tarekat MSC" sesuai hasil penelitian adalah hasil dari penjualan susu sapi (liter) dikurangi dengan biaya produksi diperoleh Rp. 10.612.750. Kondisi ini menunjukkan bahwa perusahaan mengalami kerugian karena biaya yang dikeluarkan lebih besar dari pada penerimaan. Hal ini disebabkan karena jumlah sapi yang berproduksi hanya $25 \%$ dari total sapi betina yang ada. Selain itu, produksi susu sangat rendah yaitu 5,8 liter/ekor/hari dibanding produksi susu di Bogor sebanyak 14,99 liter/ekor/hari (Hertika, 2008).

Analisis Break Even Point (BEP) merupakan salah satu teknis analisis ekonomi yang berguna dalam hubungan biaya variabel total (TVC) dan biaya tetap total (TFC) terhadap output produksi atau ukuran-ukuran lain dalam aktifitas bisnis dan industri (Gaspersz, 2002). Berdasarkan hasil penelitian, keuntungan sebesar Rp.10.612.750 diperoleh dari penjualan susu sebanyak 1060. Hal ini menunjukkan bahwat usaha ternak sapi perah "Tarekat MSC" belum mencapai BEP. Indikasinya perusahaan masih menderita kerugian. Volume penjualan/produksi susu harus dinaikkan agar Break Even Point (BEP) dapat dicapai. Apabila perusahaan mengalami kerugian maka kita mengambil volume penjualan/produksi yang lebih besar (Anonimous, 2012). Hal ini dilakukan dengan menggunakan metode trial and error, BEP dapat dicapai pada volume penjualan/produksi susu sebanyak 1767,52 liter.

Hasil penelitian menunjukkan bahwa Break Even Point (BEP) usaha ternak sapi perah "Tarekat MSC" dapat dicapai pada penerimaan/hasil penjualan susu sebesar Rp. 26.512.750 dengan volume produksi susu sebanyak 1767,52 liter per bulan. Produksi susu sebanyak 1767,52 liter dapat dicapai pada saat jumlah sapi perah laktasi sebanyak 10,16 ekor sesuai dengan produksi susu rata-rata yang ada yakni 5,8 liter/ekor/hari. Artinya keuntungan dapat dicapai apabila jumlah sapi perah di usaha "Tarekat MSC" yang berproduksi di atas 10,16 ekor atau di atas 1767,52 liter. Hasil penelitian Hertika (2008) pada usaha ternak sapi perah di Desa Cibeureum Kecamatan Cisarua Kabupaten Bogor menunjukkan titik impas atau Break Even Point (BEP) dicapai pada produksi susu sebesar 13,23 liter dengan pemeliharaan induk sebanyak 68 ekor.

\section{KESIMPULAN}

Break even point (BEP) usaha ternak sapi perah "Tarekat MSC" dapat dicapai pada penerimaan/hasil 
penjualan susu sebesar Rp. 26.512.750 dengan volume produksi susu sebanyak 1767,52 liter per bulan atau pada saat jumlah sapi laktasi sebanyak 10,16 ekor.

\section{DAFTAR PUSTAKA}

Badan Penelitian dan Pengembangan Pertanian Bogor, 2009. Profil Usaha

Peternakan Sapi Perah di Indonesia. Penerbit LIPI. Jakarta.

Gazpersz. V, 2002. Pedoman Penyusunan Rencana Bisnis. PT Gramedia Pustaka Utama. Jakarta.

Handayani S, M dan Nurlaila, I. 2011. Analisis Pemasaran Susu Segar di Kabupaten Klaten. Jurusan Agribisnis, Fakultas Pertanian, Universitas Sebelas Maret.

Hertika, S. 2008. Analisis Pendapatan Usaha Ternak Sapi Perah (Studi Kasus di Perusahaan X, Desa Cibeureum Kecamatan Cisarua Kabupaten Bogor). Program Studi Sosial Ekonomi Peternakan Fakultas Peternakan Institut Pertanian Bogor.

Putranto, E. H. 2006. Analisis Keuntungan Usaha Peternakan Sapi Perah Rakyat

di Jawa Tengah. Tesis Program Pasca Sarjana Universitas Diponegoro Semarang.

Riyanto, B. 2001. Dasar-dasar Pembelanjaan Perusahaan Ed.IV Cet VII. Penerbit BPFEE. Yogyakarta.

Siregar, S. 1995. Sapi Perah : Jenis, Teknik Pemeliharaan dan
Analisa Usaha. Penebar Swadaya. Jakarta.

1996. Efisiensi Usaha

Peternakan Sapi Perah dalam Menghadapi Era Perdagangan Bebas. Balai Penelitian Ternak Bogor.

Sudono A, R. F Rosdiana, B. S. Setiawan. 2003. Beternak Sapi Perah Secara Intensif. Penerbit Agromedia Pustaka. Bogor.

Sundari dan Katamso. Analisis Pendapatan Peternak Sapi Perah Lokal dan Eks-impor Anggota Koperasi Warga Mulya Di kabupaten Sleman Yogyakarta. Prodi Peternakan, Fakultas Agroindustri, Mercu Buana Yogyakarta

Soekardono, 2009. Ekonomi Agribisnis Peternakan Teori dan Aplikasi. Akademi Pressindo.

Syarif dan Sumoprastowo. 1985. Ternak Perah. CV Yasaguna. Jakarta. 